Emir. J. Agric. Sci. 2004. 16 (1) : 01-07

http://www.cfs.uaeu.ac.ae/research/ejas.html

\title{
Alleviating chilling injury and maintaining quality of tomato fruit by hot water treatment
}

\author{
N. M. El Assi \\ Department of Horticulture and Crop Science, College of Agriculture, University of \\ Jordan, E-mail: najibasi@ju.edu.jo
}

\begin{abstract}
Mature-green and pink tomato fruit (Solanum lycopersicom Mill., cv. Carmello) were treated with warm water for $30 \mathrm{~min}$. at $30,35,40$, or $45^{\circ} \mathrm{C}$ (non-chilled), and then either held continuously at $20{ }^{\circ} \mathrm{C}$ until red ripe (maximum 19 days), or at $4{ }^{\circ} \mathrm{C}$ (chilled) for 10 days then $20^{\circ} \mathrm{C}$ until red ripe (maximum 25 days). Fruit used to evaluate decay incidence were held at $20^{\circ} \mathrm{C}$ for an additional 6 days past the red ripe stage. When fruit reached the red-ripe stage, soluble solid contents, $\mathrm{pH}$, firmness, and weight loss were determined, decay incidence was rated and days to ripen was recorded. Chilling rather than warm water increased the fruit SSC, but neither of the treatments affected the fruit $\mathrm{pH}$. Warm water treatment enhanced firmness of fruit held at chilling temperature. Weight loss was reduced in chilled, and warm water treated fruit, except for $45{ }^{\circ} \mathrm{C}$, that showed an increase in weight loss. Non-chilled pink and mature-green tomato fruit ripened in 5 or 11 days, respectively, while chilled fruit ripened in 12 or 22 days (including a 10-day holding at chilling temperature). Pre-storage warm water treatment can be beneficial within the range of 30 to $45{ }^{\circ} \mathrm{C}$ in reducing decay, alleviating chilling injury, prolonging the storage period and improving some quality characteristics of the fruit.
\end{abstract}

Keywords: Chilling injury, decay, firmness, Solanum lycopersicom Mill, quality

تخفيف أضرار البرودة والحفاظ على جودة ثمار البندورة بالمعاملة بالماء الساخن

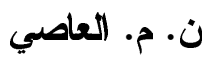

الملخص: قطفت ثمار البنلورة في مرحلتين من مراحل النضج المبكرة (خضراء ناضجة وحمر اء وردية اللون) مرة في الأسبوع

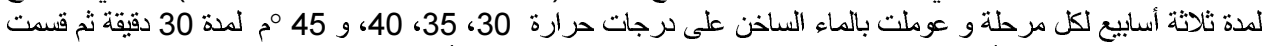

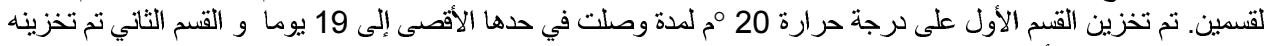

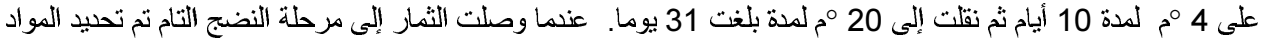

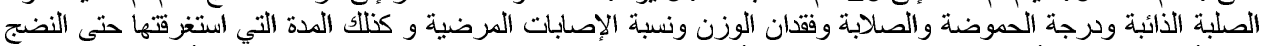

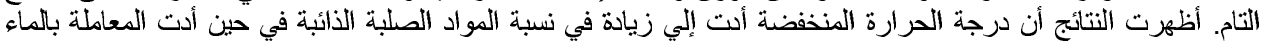

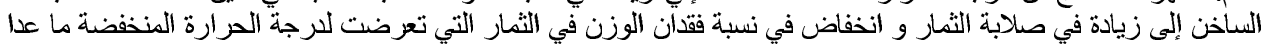

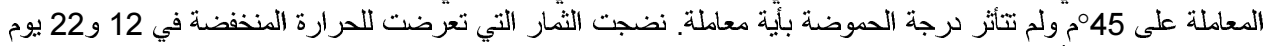

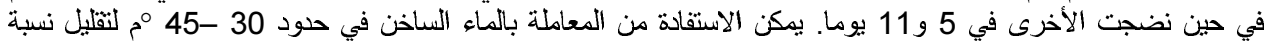

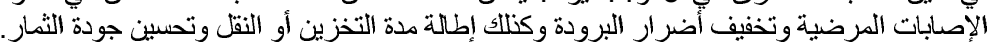

الكلمات المفتاحية: البرودة، التلف، الصلابة، نبات البنلورة، الجودة.

\section{Introduction}

Tomatoes are chilling sensitive at temperatures below $10{ }^{\circ} \mathrm{C}$ if held for longer than 2 weeks or at $5{ }^{\circ} \mathrm{C}$ for longer than $6-8$ days (Suslow and Cantwell, 2002). Consequences of chilling injury are failure to ripen and develop full color and flavor, irregular (blotchy) color development, premature softening, surface pitting, browning of the seeds, and increased decay (especially the black mold caused by
Alternaria spp.) These symptoms appear when the fruit are transferred to nonchilling temperature (Paull, 1990). In recent years, there have been several reports on the use of pre-storage heat treatments to reduce chilling injury in horticultural crops exposed to low temperature (Paull and McDonald, 1994). To date, there has been no published work concerning the use of heat treatments to reduce the detrimental effects of low temperature during transport and/or storage of Jordanian tomatoes. 
The objective of this study was to investigate the effectiveness of short-term warm water treatment to permit successful transport and/or storage of tomatoes, especially in mixed loads of different commodities in refrigerated trucks, that is mostly practiced in the export to the Gulf State markets. Fruit quality parameters, i.e. $\mathrm{SSC}, \mathrm{pH}$, firmness, and weight loss were evaluated at the red-ripe stage. Time to reach the red-ripe stage and the percentage of decay were also determined.

\section{Materials and Methods}

Tomato fruit (Solanum lycopersicom Mill. cv. "Carmello") at the mature-green and pink (more than $30 \%$ but not more than $60 \%$ of the surface shows pink or red color) stages of development were hand harvested from a commercial farm in the Jordan Valley. Three harvests were carried out for each maturity stage, with a week interval between harvests, and a ten-day interval between the two maturity stages. Harvested fruit were washed with water, air dried at ambient temperature, and transported the same day to the storage facilities located in the Jordan Valley. Fruit from each harvest were held overnight then sorted to eliminate defects and establish uniformity of size and color, and were divided into 10 groups of 20 fruit each. Two groups were not treated with warm water, the first was designated as the non-chilled control and was held at $20{ }^{\circ} \mathrm{C}$ continuously, and another was the chilled control (held at $4{ }^{\circ} \mathrm{C}$ without warm water treatment). The other eight groups were subject to warm water treatment for $30 \mathrm{~min}$ at $30,35,40$, or $45^{\circ} \mathrm{C}$, and either held at $20{ }^{\circ} \mathrm{C}$ (non-chilled) for the experiment's duration, or at $4{ }^{\circ} \mathrm{C}$ (chilled) for 10 days, and then removed to $20{ }^{\circ} \mathrm{C}$. The fruit assigned for decay evaluation were held for an additional six days once they showed the red color (full-ripe). Thus, the experiment duration for the harvested initially mature green fruit was between 17-31 days, while that for fruit harvested at the pink stage was between 11-20 days.

A water bath filled with six liters (below its capacity) of water was used to submerge 20 fruit at a time, and the desired temperature was monitored automatically. Water was changed for each treatment to avoid any possible contamination. When fruit reached the redripe ( more than $90 \%$ of the surface shows red color) stage of development, ten fruit were used for soluble solids content, $\mathrm{pH}$, and firmness determination, and another ten were used for weight loss, decay incidence, and time to ripe (changing color) evaluation. Fruit soluble solid contents were determined using a Refractometer (Abbe-Refractometer $\mathrm{Nr}$. 301, Japan, Brmer Laborhandel GMBH), reading $\mathrm{SSC}$ in ${ }^{\circ} \mathrm{Brix}$ and converting to percent. The $\mathrm{pH}$ of tomato juice was determined with a $\mathrm{pH}$ meter (Inolab $\mathrm{pH}$ level 1, Wissenschafilich Technishe Werkstaffen, Germany). Tomato fruit firmness was measured by using Fruit Pressure Tester (Effegi- 480011 Alfonsine, Italy). Fresh weight for individual fruit was taken directly upon arrival at the laboratory, and after 11 and 17 days for pink and mature-green, respectively, using a balance (Model "NCI-30" Kemerlti Cad. 69. Karakoy. Istanbul). Decay was evaluated visually by identifying diseases according to Snowdon (1991), and the percentage of diseased fruit was calculated from the total. Days to ripen was evaluated by a color chart (Color classification requirements in Unites States Standards for Grades of Fresh Tomatoes) to match the red color typical of full-ripe tomato fruit.

Complete Randomized Block Design was used to carry out three harvests with three replicates in each harvest. Analyses of variance (ANOVA) were performed using the Statistical Analysis Systems computer package (SAS Institute, 1996). Treatment 
means were compared by the Least Significant Difference test at $P=0.05$.

\section{Results and Discussion}

Soluble solids content in both mature green and pink tomato fruit, measured when reaching the red-ripe stage, was significantly higher in chilled compared to the non-chilled fruit (Tables 1 and 3). No effect of warm water treatment on the SSC of treated fruit was observed since the non-chilled fruit showed no increase in the SSC, even though, the highest value was 5.09 in the $45{ }^{\circ} \mathrm{C}$ treated fruit, but with no significant difference compared to the other treated fruit (Table 3). When measured at the red-ripe stage, SSC in pink tomato fruit were generally higher than those of mature-green. This is in agreement with Kattan (1957), stating that pink tomatoes possess higher sensory quality at the red stage than mature-green. Fruit $\mathrm{pH}$ was not affected by warm water treatment or by chilling temperature in both maturity stages, and the values at the redripe stage averaged about 4.3 which is typical of tomato fruit (Balibrea et al., 1997). Fruit firmness was affected by warm water treatment in fruit held at chilling temperatures, showing higher firmness values than those of non-chilled in both maturity stages when they reached the red-ripe stage (Tables 1 and 3). These findings agree with previous reports, stating that the chemical composition was generally unaffected by chilling, while loss of firmness was reported as a result of chilling exposure time rather than chilling temperatures per se (Chomchalow et al., 2002). Weight loss of the fruit was affected by both warm water treatment and chilling temperature. Weight loss percentages were lower in the chilled and warm water fruit treatment with low temperatures, compared to the non-chilled and chilled fruit treated with the highest warm water treatments, with significant differences (Tables 2 and 4). The highest values were always associated with the $45^{\circ} \mathrm{C}$ treatment in the four groups from both maturity stages. This might be due mainly to the effect of high temperature exposure, either at $20{ }^{\circ} \mathrm{C}$ for long periods of time, or the $45^{\circ} \mathrm{C}$ treatment on the fruit. Higher temperatures tend to increase the vapor pressure deficit and the water loss of the fruit, hence, the increase observed in the weight loss. However, the percentages of the weight loss of the $45{ }^{\circ} \mathrm{C}$ treatment in chilled fruit were still lower than

Table 1. Effect of warm water treatment and low temperature $\left(4^{\circ} \mathrm{C}\right)$ storage on mature-green tomato fruit SSC (\%), $\mathrm{pH}$, and firmness $(\mathrm{kg})$ measured after reaching the red-ripe stage

\begin{tabular}{lcccc}
\hline & Treatment & SSC $\%$ & pH & Firmness \\
\hline Non- Chilled & Control & $4.44^{\mathrm{a}}$ & $4.23^{\mathrm{a}}$ & $3.0^{\mathrm{a}}$ \\
& $30{ }^{\circ} \mathrm{C}$ & 4.53 & 4.23 & 3.1 \\
& $35^{\circ} \mathrm{C}$ & 4.58 & 4.33 & 2.8 \\
& $40^{\circ} \mathrm{C}$ & 4.59 & 4.30 & 2.9 \\
Chilled & $45^{\circ} \mathrm{C}$ & 4.48 & 4.30 & 2.7 \\
& $\mathrm{Control}$ & 4.76 & 4.29 & 3.4 \\
& $30^{\circ} \mathrm{C}$ & 4.82 & 4.30 & 3.6 \\
& $35^{\circ} \mathrm{C}$ & 4.87 & 4.29 & 3.8 \\
Significance & $40^{\circ} \mathrm{C}$ & 4.80 & 4.33 & 3.6 \\
LSD & $45^{\circ} \mathrm{C}$ & 4.72 & 4.36 & 3.6 \\
\hline
\end{tabular}

${ }^{\mathrm{a}}$ Means are the average of 90 fruit.

${ }^{\mathrm{b}}$ Non-significant (ns) or significant $\left(^{*}\right)$ at $(\mathrm{P}<0.05)$. 
those of the non-chilled (Tables 2 and 4). Decay incidence was very pronounced in both chilled and non-chilled control fruit and in the lowest warm water treatment $\left(30^{\circ} \mathrm{C}\right)$ by the increase in the percentages of decay (Tables 2 and 4). The percentages of decay were substantially reduced in fruit from all other warm water treatments. However, chilled fruit showed slightly higher percentages of decay as compared to the non-chilled fruit, but with no significant differences except for the chilled control (Tables 2 and 4). This is in agreement with Hardenburg et al., (1986), who reported that tomatoes held for two weeks or longer at 13 ${ }^{\circ} \mathrm{C}$ may develop an abnormal amount of decay and fail to develop a deep red color. A very early work (McMolloch, 1952) indicated that fruit held below $10{ }^{\circ} \mathrm{C}$ become more susceptible to Alternaria decay during subsequent ripening. It is believed that, since decay is one of the prominent symptoms of chilling injury (Cheng and Shewfelt, 1988), warm water treatments were effective, not only in reducing decay incidence, but also in alleviating chilling injury. It has been assumed that the exposure of the fruit to one type of stress may protect against another type of stress by the induction of specific factors (Lurie and Klein, 1991). Additionally, it has been suggested that the effect of heat treatment against chilling injury has been linked with some biochemical components such as increased levels of spermidine and spermine (Wang, 1994), heat shock proteins (Sabehat et al., 1996), and ethanol (Burmester et al., 1997). The highest percentage of decay incidence was recorded for the chilled control, mainly due to the absence of warm water treatment. Moreover, chilled control clearly showed the typical chilling injury symptoms, such as increased decay (Alternaria rot), pitting and delay in ripening (in pink), other chilled fruit showed no chilling injury symptoms.

Table 2. Effect of warm water treatment and low temperature $\left(4^{\circ} \mathrm{C}\right)$ storage on mature-green tomato fruit weight loss $(\%)$, decay $(\%)$, and time to ripen (days) measured after reaching the red-ripe stage

\begin{tabular}{lcccc}
\hline & Treatment & Weight Loss\% & Decay\% & Time to ripen, days \\
\hline Non- Chilled & Control & $13.5^{\mathrm{a}}$ & $44^{\mathrm{a}}$ & $12^{\mathrm{a}}$ \\
& $30^{\circ} \mathrm{C}$ & 13.8 & 22 & 13 \\
& $35^{\circ} \mathrm{C}$ & 14.2 & 19 & 12 \\
& $40^{\circ} \mathrm{C}$ & 13.9 & 19 & 11 \\
Chilled & $45^{\circ} \mathrm{C}$ & 14.5 & 10 & 11 \\
& $\mathrm{Control}$ & 8.5 & 52 & 25 \\
& $30^{\circ} \mathrm{C}$ & 8.3 & 24 & 24 \\
& $35^{\circ} \mathrm{C}$ & 8.2 & 21 & 24 \\
Significance & $40^{\circ} \mathrm{C}$ & 9.3 & 21 & 22 \\
LSD & $45^{\circ} \mathrm{C}$ & 10.2 & 13 & 23 \\
\hline
\end{tabular}

${ }^{\mathrm{a}}$ Means are the average of 90 fruit.

${ }^{\mathrm{b}}$ Non-significant $(\mathrm{ns})$ or significant $\left({ }^{*}\right)$ at $(\mathrm{P}<0.05)$. 
The typical color of tomato was used as an indication for ripening, and the days elapsed prior to that were considered as time to ripen. Tomato fruit from both maturity stages treated with warm water at $45{ }^{\circ} \mathrm{C}$ developed the highest color intensity compared to all other treatments. This was detectable at early stage of the red-ripe stage but was unnoticeable toward the end of the experiment. Non-chilled maturegreen tomato fruit held continuously at 20 ${ }^{\circ} \mathrm{C}$ showed typical red color after 11 days (Table 2), while the pink tomato fruit were already red colored at the fifth day (Table 4). Ripening period was longer for the chilled fruit because of the 10-day holding at chilling temperatures, which substantially reduced the metabolic rates of the fruit, delaying ripening and prolonging their storage period. Once removed from the chilling temperatures, the ripening process was accelerated in the pink tomatoes and within 2 to 5 days they attained full red color, whereas, it took 12 to 15 days for mature-green fruit to reach that stage. However, the chilled mature-green tomato fruit showed a delay of 1-2 days in attainment of the full red color (red-ripe) as compared to their counterparts from the non-chilling group. It has been reported that a decrease in chlorophyll and an increase in lycopene in Vibelco tomato fruit were observed in response to both warm water and time (Hakim et al., 1997). This would have been true if the fruit were subject to chilling temperature, without heat treatment, which supposedly will delay ripening. Some differences exist though between the two experiments since the effect in the current work was observed only on mature-green fruit but not in the pink fruit. It has been postulated that differences in cultivars may show some differences in quality characteristics in response to heat treatment (Whitaker, 1994a; Lurie and Sabehat, 1997; McDonald et al., 1998).

Table 3. Effect of warm water treatment and low temperature $\left(4^{\circ} \mathrm{C}\right)$ storage on pink tomato fruit $\mathrm{SSC}(\%), \mathrm{pH}$, and firmness $(\mathrm{kg})$ measured after reaching the red-ripe

\begin{tabular}{|c|c|c|c|c|}
\hline \multicolumn{5}{|c|}{ stage } \\
\hline & Treatment & $\mathrm{SSC} \%$ & pH & Firmness \\
\hline \multirow[t]{5}{*}{ Non- Chilled } & Control & $4.65^{\mathrm{a}}$ & $4.40^{\mathrm{a}}$ & $3.3^{\mathrm{a}}$ \\
\hline & $30^{\circ} \mathrm{C}$ & 4.71 & 4.36 & 3.0 \\
\hline & $35^{\circ} \mathrm{C}$ & 4.62 & 4.33 & 2.9 \\
\hline & $40^{\circ} \mathrm{C}$ & 4.46 & 4.30 & 2.8 \\
\hline & $45^{\circ} \mathrm{C}$ & 4.40 & 4.40 & 3.1 \\
\hline \multirow[t]{5}{*}{ Chilled } & Control & 5.02 & 4.31 & 3.3 \\
\hline & $30^{\circ} \mathrm{C}$ & 5.00 & 4.30 & 3.4 \\
\hline & $35^{\circ} \mathrm{C}$ & 4.51 & 4.33 & 3.4 \\
\hline & $40^{\circ} \mathrm{C}$ & 5.05 & 4.26 & 3.1 \\
\hline & $45^{\circ} \mathrm{C}$ & 5.09 & 4.27 & 3.3 \\
\hline Significance $^{b}$ & & $*$ & ns & $*$ \\
\hline LSD & & 0.39 & - & 0.40 \\
\hline
\end{tabular}

${ }^{\mathrm{a}}$ Means are the average of 90 fruit.

${ }^{\mathrm{b}}$ Non-significant (ns) or significant $(*)$ at $(\mathrm{P}<0.05)$. 
Table 4. Effect of warm water treatment and low temperature $\left(4^{\circ} \mathrm{C}\right)$ storage on pink tomato fruit weight loss $(\%)$, decay (\%), and time to ripen (days) measured after reaching the red-ripe stage

\begin{tabular}{lcccc}
\hline & Treatment & Weight Loss\% & Decay\% & Time to ripen, days \\
\hline Non-Chilled & Control & $7.3^{\mathrm{a}}$ & $18^{\mathrm{a}}$ & $5^{\mathrm{a}}$ \\
& $30^{\circ} \mathrm{C}$ & 6.9 & 11 & 6 \\
& $35^{\circ} \mathrm{C}$ & 7.1 & 11 & 5 \\
& $40^{\circ} \mathrm{C}$ & 7.6 & 10 & 5 \\
Chilled & $45^{\circ} \mathrm{C}$ & 8.2 & 7 & 5 \\
& Control & 5.6 & 21 & 15 \\
& $30^{\circ} \mathrm{C}$ & 5.3 & 11 & 14 \\
& $35^{\circ} \mathrm{C}$ & 4.7 & 11 & 14 \\
Significance & $40^{\circ} \mathrm{C}$ & 4.8 & 12 & 13 \\
LSD & $45^{\circ} \mathrm{C}$ & 6.1 & 6 & 12 \\
& $*$ & $*$ & $*$ & \\
\hline
\end{tabular}

${ }^{\mathrm{a}}$ Means are the average of 90 fruit.

${ }^{\mathrm{b}}$ Non-significant (ns) or significant $\left({ }^{*}\right)$ at $(\mathrm{P}<0.05)$.

\section{Conclusions}

Warm water treatment of mature-green and pink tomato fruit prior to holding at chilling temperature $\left(4^{\circ} \mathrm{C}\right)$ apparently reduced decay incidence, which can be considered as a chilling injury symptom, as well as other chilling injury symptoms. Such treatment increased the firmness and SSC but had no effect on the fruit $\mathrm{pH}$. No harmful effect of warm water treatments were observed within the range used in this study $\left(30-45{ }^{\circ} \mathrm{C}\right)$, although water loss was higher for fruit treated at $45^{\circ} \mathrm{C}$.

It is recommended, though, to use such treatment in order to improve the quality characteristics of the tomato fruit, mainly if stored or transported at chilling temperature in mixed loads. The beneficial effects of such technology are in its ability to prolong storage and/or transport period required to export marketing while reducing fruit loss to decay.

\section{References}

Balibrea, M. E., E. Cayuela, F. Artes and F. D. Alfocea. 1997. Salinity effects on some post harvest quality factors in commercial tomato hybrid. J. Hort. Sci., 72 (6): 885-892.

Burmeister, D. M., S. Ball, S. Green and A. B. Woolf. 1997. Interaction of warm water treatments and controlled atmosphere storage on quality of Fuyu persimmons. Postharvest Biol. Technol. 12: $71-81$.

Cheng, T. S. and R. L. Shewfelt. 1988. Effect of chilling exposure of tomatoes during subsequent ripening. J. Food. Sci. 53: 1160-1162.

Chomchalow, S., N. M. El Assi, S. A. Sargent and J. K. Brecht. 2002. Fruit maturity and timing of ethylene treatment affect storage performance of mature green tomatoes at chilling and 
nonchilling temperature. HortTechnology 12 (1): 104-114.

Hakim, A., E. Kaukovirta, E. Pehu and I. Voipio. 1997. Effect of warm water, immersion time, and length of storage on chilling injury of tomato fruit. J.Veg. Crop Prod. 3:17-27.

Hardenburg, R. E., A. E. Watada and C. Y. Wang. 1986. The commercial storage of fruits, vegetables, and florist and nursery stocks. Agricultural Handbook 66. U.S. Department of Agriculture, Agriculture Research Service.

Lurie, S. and J. D. Klein. 1991. Acquisition of low temperature tolerance in tomatoes by exposure by high temperature stress. J. Am. Soc. Hort. Sci. 116: 1007-1012.

Lurie, S. and A. Sabehat. 1997. Prestorage temperature manipulation to reduce chilling injury in tomatoes. Postharvest Biol. Technol. 11: 57-62.

Kattan, A. A. 1957. Changes in color and firmness during ripening of detached tomatoes and the use of a new instrument for measuring firmness. Proc. Amer. Soc. Hort. Sci. 70: 379384.

McDonald, R. E., T. G. McCollum and E. A. Baldwin. 1996. Prestorage heat treatments influence the sterols and flavor volatiles of tomatoes stored at chilling temperature. J. Am. Soc. Hort. Sci. 12: 531-536.

McMolloch, L. P. and J. T. Worthington. 1952. Low temperature as a factor in the susceptibility of mature-green tomatoes to Alternaria rot. Phytopathology. 42: 425-427.
Paull, R. E. 1990. Chilling injury of crops of tropical and subtropical origin. In: Wang, C. Y (Ed). PP. 17-36, Chilling Injury of Horticultural Crops. CRC Press, Roca Raton, Fl.

Paull, R. E. and R. E. McDonald. 1994. Heat and cold treatments. In: Paull, R. E., and J.W. Armstrong (Eds). PP. 191223. Insect Pests and Fresh Horticultural Products: Treatments and Responses. CAB International, Wallington, U.K.

Sabehat, A., D. Weiss, and S. Lurie. 1996. The correlation between heat-shock protein accumulation and persistence and chilling tolerance in tomato fruit. Plant Physiol. 110: 531-537.

Statistical Analysis System (SAS) Institute. 1996. Statistical analysis systems computer package. Cary, NC, USA.

Snowdon, A. L. A.1991. Colour Atlas of Post-Harvest Diseases and Disorders of Fruits and Vegetables. Vol. 2: Vegetables. BPCC Hazell Books, Aylesbury, England.

Suslow, T. V. and M. Cantwell. 2002. Recommendations for Maintaining Postharvest Quality of Horticultural Commodities. Produce Facts, Tomato. Postharvest Horticulture Series No. 20.

Wang, C. Y. 1994. Combined treatment of heat shock and low temperature conditioning reduces chilling injury in Zucchini squash. Postharvest Biol. Technol. 4: 65-73.

Whitaker, B. D. 1988. Changes in steryl lipid content and composition of tomato fruit during ripening. Phytochemistry. 27: $3411-3516$. 